\title{
Evaluasi Pengelolaan Obat di Instalasi Farmasi Dinas Kesehatan Kota Surakarta Tahun 2015
}

\section{Evaluation of Drug Supply Management at Pharmacy Installation of Surakarta Health Office on 2015}

\author{
Ganet Eko Pramukantoro', Sunarti \\ ${ }^{12}$ Pharmacy Faculty, Universitas Setia Budi, Jl. Letjen Sutoyo No.6, Mojosongo, Jebres, Kota Surakarta, Jawa Tengah \\ 57127, Indonesia \\ ganetep@gmail.com
}

\begin{abstract}
ABSTRAK
Manajemen obat merupakan proses penting dalam pelayanan kesehatan masyarakat. Manajemen obat yang tidak tepat dapat memberikan efek negatif pada kualitas layanan kesehatan di Kabupaten / Kota. Tujuan penelitian ini adalah untuk memberikan gambaran umum dan melakukan evaluasi manajemen persediaan obat yang meliputi pemilihan, pengadaan, distribusi, dan penggunaan di Instalasi Farmasi Departemen Kesehatan Surakarta.

Data dikumpulkan secara retrospektif dengan menelusuri dokumen tahun-tahun sebelumnya. Semua dokumen selama proses seleksi, pengadaan, distribusi, dan penggunaan obat dimasukkan sebagai bahan penelitian. Data yang diperoleh kemudian dievaluasi dan dibandingkan dengan standar menurut WHO dan Kementerian Kesehatan (2010).

Manajemen persediaan obat di Instalasi Farmasi Kota Surakarta sesuai standar WHO dan Kementerian Kesehatan (2010) adalah sebagai berikut: Ketersediaan obat sesuai kebutuhan $(102,84 \%)$, pengadaan obat esensial $(86,87 \%)$, pengadaan obat generik $(100 \%)$, obat tersedia dibandingkan to DOEN $(60.22 \%)$ dan ketepatan perencanaan $(88.94 \%)$. Tingkat ketersediaan obat $(100 \%)$, kelayakan distribusi obat $(29,41 \%)$, jumlah obat yang didistribusikan secara tidak tepat $(9,84 \%)$, dan waktu rata-rata kekosongan obat $(0 \%)$. Tingkat akurasi item obat dengan Fornas I (60,77\%). Penelitian kami menyimpulkan bahwa manajemen obat di Departemen Farmasi Surakarta masih memerlukan peningkatan terutama pada proses distribusi dan penggunaan sesuai standar WHO dan Kementerian Kesehatan (2010).
\end{abstract}

Kata kunci :Pengelolaan obat, Instalasi Farmasi, Analisis Efisiensi.

\footnotetext{
ABSTRACT

Drug management is an important process in public health service. Inappropriate drug management may exert negative effect on the quality of healthcare service in a District/City. The purpose of this study was to provide an overview and evaluation of drug supply management that includes: selection, procurement, distribution, and use in Pharmacy Installatio of Surakarta Health Department.

Data was collected retrospectively by tracing the documenst from previous years. All process of selection, procurement, distribution, and usage were included. The obtained data were evaluated and compared with the standard according to WHO and Ministry of Health (2010).

Drug supply management in Pharmacy Department of Surakarta according to the standards as follows : The availability of the drug as needed $(102.84 \%)$, procurement of essential drug (86.87\%), procurement of generic drug (100\%), drug availability compared to DOEN (60.22\%) and planning accuracy (88.94\%). Drug availability level (100\%), drug distribution appropriateness $(29,41 \%)$, the number of drug distributed inappropriately $(9,84 \%)$, and the avarage time of drug emptiness $(0 \%)$. The accuracy level of drugs item with Fornas I $(60,77 \%)$. Our study concluded that drug management in Pharmacy Installation of Surakarta Health Office still need improvement especially on distribution and utilization process according to WHO and Ministry of Health (2010) standards.

Key word : Drug Management, Pharmacy Departement, Efficiency analysis.
} 


\section{PENDAHULUAN}

Obat dan perbekalan kesehatan merupakan komponen yang tak tergantikan dalam pelayanan kesehatan. Akses terhadap obat dan perbekalan kesehatan terutama obat esensial merupakan salah satu hak asasi manusia, dengan demikian penyediaan obat esensial juga merupakan kewajiban bagi pemerintah untuk mendukung pelayanan kesehatan kepada masyarakat. .

Salah satu hal penting dalam pelayanan kesehatan adalah pengelolaan obat. Instalasi Farmasi Kabupaten/Kota adalah tempat dimana semua obat yang datang disimpan untuk didistribusikan ke puskesmas. Penyimpanan dan distribusi merupakan bagian dalam fungsi pengelolaan obat yang penting guna menjamin mutu obat yang akan digunakan untuk pelayanan kesehatan di puskesmas.

Sebelum otonomi daerah, fungsi pengelolaan obat di seluruh kabupaten/kota dilaksanakan oleh Gudang Farmasi Kabupaten (GFK) yang bertanggung jawab sepenuhnya atas kebutuhan obat ditingkat Kabupaten/kota. Pengadaan obat dilakukan oleh pemerintah pusat dalam hal ini Departemen Kesehatan, sedangkan setelah desentralisasi pengadaan obat dilakukan oleh masing-masing Dinas Kesehatan Kabupaten/kota (UU 32 tahun 2004).

Pengelolaan obat merupakan siklus kegiatan, dimulai dari pemilihan, perencanaan, penerimaan, pendistribusi an, pencatatan dan pelaporan obat untuk mencapai suatu tujuan tertentu yang dilakukan secara efektif dan efisien

Pengelolaan obat pada tahap perencanaan dan pengadaan (procurement) merupakan proses kegiatan dalam mewujudkan ketersediaan obat untuk mencapai pelayanan kesehatan yang bermutu. Instalasi farmasi sering menghadapi permasalahan pada tahap seleksiyaitu dalam pemilihan obat yang diperlukan sesuai dengan kebutuhan kesehatan masyarakat yang ada di daerah, sedangkan pada tahap perencanaan dan pengadaan adanyaketidaksesuaian antara perencanaan obat tahunan dengan pembelian, fluktuasi pemakaian obat-obat dan kebijakan pemerintah yang mengalami perubahan. Pengelolaan obat yang tidak efisien menyebabkan tingkat ketersediaan obat menjadi berkurang, terjadi kekosongan obat, banyaknya obat yang menumpuk akibat tidak sesuainya perencanaan obat, serta banyaknya obat yang kadaluwarsa/rusak akibat sistem distribusi yang kurang baik sehingga dapat berdampak kepada inefisiensi penggunaan anggaran/biaya obat di tingkat Kabupaten/Kota (MSH 2012).

Permasalahan yang sering dijumpai dalam perencanaan obat adalah membeli terlalu banyak, membeli obat yang tidak diperlukan, tidak memperhitungkan umur obat sehingga mengakibatkan pemborosan karena terjadi obat-obat kadaluwarsa (Siregar 2004).

Distribusi obat yang baik harus menyelenggarakan suatu sistem jaminan kualitas sehingga obat yang 
didistribusikan terjamin mutu/kualitas, keamanan, dan keabsahannya sampai ke tangan masyarakat. Distribusi obat yang tidak efisien menyebabkan tingkat ketersediaan obat menjadi berkurang, terjadi kekosongan obat, banyaknya obat yang menumpuk akibat dari perencanaan obat yang tidak sesuai serta banyaknya obat yang kadaluwarsa/rusak yang disebabkan sistem distribusi yang kurang baik sehingga akan berdampak kepada inefisiensi penggunaan anggaran/biaya obat di tingkat Kabupaten/Kota (MSH 2012).

Mengingat pentingnya pengelolaan obat dalam rangka mencapai pelayanan yang bermutu, maka perlu dilakukan evaluasi terhadap pelaksanaan pengelolaan obat untuk mengetahui adanya permasalahan atau kelemahan dalam pelaksanaannya, selanjutnya dapat dilakukan tindakan perbaikan untuk meningkatkan pelayanan kesehatan.

\section{METODE PENELITIAN}

Penelitian menggunakan rancangan deskriptif dengan pengambilan data secara retrospektif dan concurent. Data retrospektif yaitu data yang diperoleh dengan penelusuran terhadap dokumen tahun tahun 2015 antara lain laporan perencanaan dan pemakaian obat, laporan keuangan, laporan pengadaan obat, faktur, laporan stok opname, laporan pemusnahan obat rusak dan kadaluwarsa. Data concurent adalah data yang diperoleh pada saat penelitian tahun 2016 atau merupakan data primer antara lain kartu stok, jumlah item obat tiap lembar resep, persentase resep dengan obat generik, rata-rata waktu yang digunakan untuk melayani resep sampai ke tangan pasien, persentase obat yang diberi label dengan benar.

Pengambilan data retrospektif dilakukan pada indikator kesesuaian item obat yang tersedia dengan DOEN, persentase modal/dana yang tersedia dengan keseluruhan dana yang dibutuhkan, persentase alokasi dana pengadaan obat, persentase kesesuaian antara perencanaan obat dengan kenyataan pakai untuk masingmasing obat, frekuensi pengadaan tiap item obat, frekuensi kesalahan faktur, frekuensi tertundanya pembayaran oleh rumah sakit terhadap waktu yang telah ditetapkan, Turn Over Ratio, persentase nilai obat kadaluwarsa dan rusak, persentase obat stock mati, sedangkan pengambilan data concurent dilakukan pada indikator kecocokan antara obat dengan kartu stock, jumlah item obat tiap lembar resep, persentase penulisan resep obat generik, persentase obat yang dilabeli dengan benar.

\section{HASIL DAN PEMBAHASAN}

\section{Tahap Selection}

a. Kesesuaian item obat yang tersedia dengan Fornas Tingkat I

Pemilihan obat di Kabupaten/Kota mengacu pada Fornas I dan harga obat yang tercantum dalam e-catalog, data diambil secara retrospektif pada tahun 2015. Persentase kesesuaian item obat yang tersedia dalam Fornas Tingkat I diperoleh dari total jenis obat yang tersedia yang masuk dalam Fornas Tingkat I dibagi dengan total jenis obat yang tersedia di Gudang Farmasi 
dikalikan dengan $100 \%$, dapat dilihat pada tabel 1 .

Tabel 1. Kesesuaian item obat yang tersedia dengan Fornas Tingkat I

\begin{tabular}{lcc}
\hline \multicolumn{1}{c}{ Keterangan } & $\begin{array}{l}\text { Nilai } \\
\text { (item) }\end{array}$ & $\begin{array}{c}\text { Nilai } \\
\text { Standar }\end{array}$ \\
\hline $\begin{array}{l}\text { Jumlah itemobat yang } \\
\text { tersedia di Gudang }\end{array}$ & 181 & - \\
Farmasi DKK & & - \\
$\begin{array}{l}\text { Jumlah item obat yang } \\
\text { tersedia di Gudang }\end{array}$ & 110 & - \\
$\begin{array}{l}\text { Farmasi DKK yang } \\
\text { masukFornas Tingkat 1 }\end{array}$ & & \\
\hline $\begin{array}{l}\text { \% Kesesuaian item obat } \\
\text { yang tersediadenganFornas } \\
\text { Tingkat 1 }\end{array}$ & 60,77 & $100 \%$ \\
& & \\
\hline
\end{tabular}

Sumber : Instalasi Farmasi Dinas Kesehatan Surakarta

Berdasarkan tabel 1 terlihat bahwa kesesuaian obat yang tersedia di Surakarta bila dibandingkan dengan Fornas tingkat I pada tahun 2015 dibawah standar kesesuaian dengan Fornas Tingkat I yaitu sebesar $60,77 \%$. Menurut hasil wawancara dengan Kepala Gudang Farmasi menyatakan bahwa seleksi obat dilakukan oleh kepala Gudang Farmasi berdasarkan usulan jenis-jenis obat dari masingmasing Puskesmas yang ada di Wilayah Kota Surakarta. Untuk pengadaan obat yang dilakukan sudah mengacu pada Fornas I namun memang kebutuhan obat masyarakat di Surakarta ada yang di luar Formularium Nasional.

\section{b. Ketersediaan Obat Sesuai Kebutuhan.}

Nilai ketersediaan obat sesuai kebutuhan di Instalasi Farmasi Kota Surakarta dapat dilihat pada Tabel 2
Tabel 2 Ketersediaan obat sesuai kebutuhan

\begin{tabular}{cccc}
\hline $\begin{array}{c}\text { Item } \\
\text { obat } \\
\text { yang } \\
\text { tersedia }\end{array}$ & $\begin{array}{c}\text { Item obat } \\
\text { yang } \\
\text { dibutuhkan }\end{array}$ & Persentase & Standar \\
& & & $\begin{array}{c}\text { (DepKes, } \\
\text { 2010) }\end{array}$ \\
\hline 181 & 176 & $102,84 \%$ & $90 \%$ \\
\hline $\begin{array}{l}\text { Sumber } \\
\text { KesehatanSurakarta }\end{array}$ & Farmasi & Dinas \\
\end{tabular}

Tabel 2 menunjukkan hasil sebesar $102,84 \%$. Ini menunjukkan ketersediaan obat untuk pelayanan kesehatan dasar yang dipenuhi oleh pemerintah sebesar 102,84\%. Dalam Peraturan Walikota SurakartaNomor 4A Tahun 2010 Tentang Standar Pelayanan Minimal Kesehatan dijelaskan bahwa ketersediaan obat sesuai kebutuhan adalah $90 \%$. Hasil tersebut menunjukkan bahwa ketersediaan obat sesuai kebutuhan sudah memenuhi standar (Perwali 2010) yaitu minimal sebesar $90 \%$. Dengan adanya ketersediaan dan kecukupan obat merupakan indikasi kesinambungan pelayanan obat untuk mendukung pelayanan kesehatan di Kota Surakarta. Ketersediaan yang baik adalah ketersediaan yang optimal tanpa kekurangan ataupun kelebihan stok yang besar (Risqi H dkk 2016).

Terdapat beberapa obat yang tidak dibutuhkan tetapi tersedia di Instalasi Farmasi Kota Surakarta. Contohnya artesunate inj. Obat tersebut hanya digunakan untuk kasus-kasus tertentu saja, selain itu kuinin inj dan primakuin tablet. Obat tersebut digunakan untuk penyakit malaria, yang mana penyakit tersebut jarang terjadi tetapi memang 
obat tersebut harus tersedia jika sewaktu-waktu dibutuhkan.

\section{Tahap Procurement}

Perencanaan merupakan tahap yang penting dalam pengadaan obat di Dinas Kesehatan, apabila terjadi kelemahan dalam sistem perencanaan tersebut, maka akan mengakibatkan kekacauan dalam sistem pengelolaan obat, misalnya: terjadi pemborosan anggaran, banyaknya obat tidak terpakai/terbuang, membengkaknya anggaran pengadaan dan penyimpanan. Pengadaan Obat Esensial.

Tabel 3. Pengadaan obat esensial

\begin{tabular}{cccc}
\hline $\begin{array}{c}\text { Jumlah } \\
\text { item } \\
\text { obat }\end{array}$ & $\begin{array}{c}\text { Nilai obat } \\
\text { esensial } \\
\text { yang } \\
\text { disimpan di } \\
\text { IF }\end{array}$ & $\begin{array}{c}\text { Nilai total } \\
\text { obat yang } \\
\text { disimpan di } \\
\text { IF }\end{array}$ & Persentase \\
\hline 31 & $\mathrm{Rp}$ & $\mathrm{Rp}$ & $86,87 \%$ \\
& 462.782 .750 & 532.735 .750 & \\
\hline
\end{tabular}

Sumber: Instalasi Farmasi Dinas Kesehatan Surakarta

Nilai obat esensial yang disimpan di Instalasi Farmasi Kota Surakarta dapat dilihat pada Tabel 3, hasil tersebut menunjukkan rata-rata sebesar $86,87 \%$ dari total nilai obat yang disimpan. Dalam Peraturan Walikota Surakarta Nomor 4-A Tahun 2010 Tentang Standar Pelayanan Minimal Kesehatan dijelaskan bahwa pengadaan obat esensial adalah $100 \%$. Hasil tersebut menunjukkan bahwa pengadaan obat esensial belum sesuai dengan standar (Perwali 2010) yaitu sebesar $100 \%$. Sehingga obat yang disimpan dalam Instalasi Farmasi Kota Surakarta belum semua obat esensial.

Kesesuaian jenis obat yang tersedia di Instalasi Farmasi Kota Surakarta bila dibandingkan dengan jenis obat esensial yang ada pada Daftar Obat Esensial Nasional (DOEN) tahun 2015 rata-rata sebesar 60,44\%. Ini menunjukkan Instalasi Farmasi Kota Surakarta belum mengutamakan pengadaan obat yang mengacu pada DOEN. Kesesuaian jenis obat dengan DOEN merupakan upaya untuk meningkatkan efektivitas dan efisiensi pemanfaatan dana pengadaan obat.

Tabel 4. Pengadaan obat generic

\begin{tabular}{cccc}
\hline $\begin{array}{c}\text { Jumlah } \\
\text { item } \\
\text { obat }\end{array}$ & $\begin{array}{c}\text { Nilai } \\
\text { obat } \\
\text { generik } \\
\text { yang } \\
\text { disimpa } \\
\text { n di IF }\end{array}$ & $\begin{array}{c}\text { Nilai total } \\
\text { obat yang } \\
\text { disimpan } \\
\text { di IF }\end{array}$ & Persen \\
& & & \\
\hline 31 & $\mathrm{Rp}$ & $\mathrm{Rp}$ & $100 \%$ \\
& 532.735. & 532.735 .7 & \\
& 750 & 50 & \\
\hline
\end{tabular}

Sumber: Instalasi Farmasi Dinas Kesehatan Surakarta

Nilai obat generik yang disimpan atau diadakan oleh Instalasi Farmasi Kota Surakarta dapat dilihat pada Tabel 4 menunjukkan rata-rata sebesar 100 $\%$ dari total nilai obat yang disimpan atau dana obat yang disediakan. Dalam Peraturan Walikota Surakarta Nomor 4A Tahun 2010 Tentang Standar Pelayanan Minimal Kesehatan dijelaskan bahwa pengadaan obat generik adalah 100\%. Hasil tersebut menunjukkan bahwa pengadaan obat generik sudah memenuhi standar (Perwali 2010) yaitu sebesar $100 \%$. 
Penerapan obat generik harus dilaksanakan secara konsisten dan terus-menerus di semua Unit Pelayanan Kesehatan. Hal ini sejalan dengan Peraturan Menteri Kesehatan Republik Indonesia Nomor HK.02.02/MENKES/068/I/2010 tentang Kewajiban Menggunakan Obat Generik di Fasilitas Kesehatan Milik Pemerintah, maka hanya obat generik saja yang diperbolehkan tersedia di pelayanan kesehatan milik pemerintah termasuk Puskesmas dan Rumah Sakit Umum Daerah (RSUD) milik daerah.

Dalam Peraturan Menteri Kesehatan Republik Indonesia Nomor HK.02.02/MENKES/068/I/2010 tentang kewajiban menggunakan obat generik di fasilitas pelayanan kesehatan pemerintah, menyebutkan bahwa kebijakan pemerintah dalam hal ini Departemen Kesehatan RI tentang obat generik antara lain mewajibkan penyediaan obat generik untuk kebutuhan pasien rawat jalan dan rawat inap dalam bentuk formularium, Dinas kesehatan Provinsi dan Dinas Kesehatan Kabupaten atau Kota wajib menyediakan obat esensial dengan nama generik untuk kebutuhan puskesmas dan unit pelaksana teknis lainnya sesuai kebutuhan, dokter yang bertugas di fasilitas pelayanan kesehatan pemerintah wajib menuliskan resep obat generik bagi semua pasien sesuai indikasi medis, apoteker dapat mengganti obat merk dagang atau obat paten dengan obat generik yang sama komponen aktifnya atau obat merk dagang lain atas persetujuan dokter dan atau pasien, dokter di rumah sakit, puskesmas dan unit pelaksana teknis lainnya dapat menyetujui penggantian resep obat generik dengan resep obat generik bermerk atau bermerk dagang dalam hal obat generik tertentu belum tersedia.

Fasilitas pelayanan kesehatan pemerintah, pemerintah daerah wajib menyediakan obat generik untuk pasien rawat jalan dan rawat inap dengan penyediaan obat generik berdasarkan formularium yang telah disusun oleh fasilitas pelayanan kesehatan yang dimaksud dan formularium tersebut mengacu kepada DOEN.

Instalasi Farmasi Kota Surakarta melakukan pemantauan pelaksanaan penulisan resep obat generik untuk penulisan resep di Puskesmas. Untuk pemantauan pelaksanaan penyediaan obat generik dilakukan oleh satuan pengawas internal penyediaan obat generik di Instalasi Farmasi Kota Surakarta untuk Puskesmas.

Selain hal-hal tersebut, kemungkinan juga dalam pengadaan obat generik mempertimbangkan dari segi harga. Harga obat generik lebih murah karena dijual dalam kemasan yang sederhana dan tidak ada biaya untuk promosi. Penyebab harga obat mahal antara lain adanya biaya promosi yang bisa mencapai $20-30 \%$. Sehingga akan mempengaruhi harga obat yang signifikan. Harga obat generik dikendalikan dan dipantau oleh pemerintah, dalam hal ini oleh Kementerian Kesehatan. Meskipun harganya terjangkau, obat generik tetap terjamin mutu, khasiat dan keamanannya karena obat generik diproduksi oleh perusahaan farmasi yang telah menerapkan Cara Pembuatan Obat Yang Baik (CPOB) 
dengan standar yang ditetapkan oleh Badan Pengawas Obat dan Makanan (Badan POM).

Tabel 5. Kesesuaian item obat yang tersedia dengan DOEN

\begin{tabular}{cccc}
\hline $\begin{array}{c}\text { Jumlah } \\
\text { item } \\
\text { obat }\end{array}$ & $\begin{array}{c}\text { Jumlah } \\
\text { jenis } \\
\text { obat } \\
\text { yang } \\
\text { termasuk } \\
\text { dalam } \\
\text { DOEN }\end{array}$ & $\begin{array}{c}\text { Jumlah } \\
\text { jenis } \\
\text { obat } \\
\text { yang } \\
\text { tersedia }\end{array}$ & Persen \\
& & & \\
\hline 181 & 109 & 181 & $60,22 \%$
\end{tabular}

Sumber: Instalas iFarmasi Dinas Kesehatan Surakarta

Nilai kesesuaian item obat yang tersedia dengan DOEN di Instalasi Farmasi Kota Surakarta tahun 2015 dapat dilihat pada Tabel 5 menunjukkan rata-rata sebesar 60,22 $\%$, sedangkanidealnya menurut Departemen KesehatanRI indikatornya adalah $\quad 100 \%$. Ini lebih baikdibandingkan dengan yang terdapat di Instalasi Farmasi Kabupaten Papua Wilayah Selatan yaitu 57,81\% (Waluyo et al 2015). Ada tujuh puluh dua obat yang tidak masuk dalam daftarDOEN. Akan tetapi masuk dalam Formularium Nasional dan Formularium Obat Puskesmas.

Obat-obat yang disimpan dalam Instalasi Farmasi Kota Surakarta dan obat-obat yang digunakan masingmasing puskesmas di Kota Surakarta belum semua obat esensial, akan tetapi terdapat juga obat yang termasuk dalam daftar Formularium Nasional dan Formularium Obat Puskesmas. Dalam Formularium Obat Puskesmas tersebut berisi daftar obat-obat yang digunakan dalam pelayanan kesehatan dasar, di luar obat-obat DOEN. Formularium Obat Puskesmas tersebut dibuat oleh tim perencana obat dimana dalam penyusunan Formularium Obat Puskesmas tersebut mengacu berdasarkan pertimbangan kebutuhan obat yang sebelumnya telah diusulkan oleh masing-masing puskesmas. Ketersediaanobat-obat tersebut karena adanya usulan dari Puskesmas dengan pertimbangan tingkat urgensi dan kebutuhan obat dalam pelayanan kesehatan dasar. Kesesuaian jenis obat dengan DOEN merupakan upaya untuk meningkatkan efektivitas dan efisiensi pemanfaatan dana pengadaan obat.

\section{Tahap Distribution}

Tabel 6. Persentase Ketepatan Distribusi Obat

\begin{tabular}{clcc}
\hline No. & Keterangan & Jumlah & Persen \\
\hline 1. & $\begin{array}{l}\text { Puskesmas } \\
\text { yang } \\
\text { dilayanisesuair } \\
\text { encana }\end{array}$ & 5 & $29,41 \%$ \\
\hline 2. & $\begin{array}{l}\text { Puskesmas } \\
\text { yang } \\
\text { dilayanitidakse } \\
\text { suairencana }\end{array}$ & 12 & $70,59 \%$ \\
\hline
\end{tabular}

Total $17 \quad 100 \%$

Sumber: Instalasi Farmasi Dinas Kesehatan Surakarta

Hanya terdapat lima Puskesmas yang dilayani sesuai dengan rencana dari 17 Puskesmas yang terdapat di wilayah Kota Surakarta. Ketepatan distribusi dapat dilihat dari perencanaan distribusi dan pendistribusiannya ke Puskesmas pada hari yang sama. Angka ideal dari indikator ketepatan distribusi obat berdasarkan Dinkes Provinsi Jateng (2006) adalah sebear $100 \%$. Sedangkan hasil yang didapatkan dari penelitian hanya 
sebesar $29,41 \%$. Hasil ini menunjukkan belum sesuainya distribusi yang dilakukan oleh Instalasi Farmasi Dinas Kesehatan Kota Surakarta karena perbedaan persentase yang cukup signifikan.

Ketidaktepatan pendistribusian obat yang dilakukan oleh Instalasi Farmasi Dinas Kesehatan Kota Surakarta ini dikarenakan perbedaan sistem pendistribusian di Instalasi Farmasi Dinas Kesehatan Kota Surakarta yang berbeda dengan indikaor. Pada indikator standar dari Kementerian Kesehatan disebutkan bahwa Instalasi Farmasi Dinas Kesehatan Kabupaten/Kota seharusnya melakukan perencanaan distribusi dan pendistribusian ke tiap - tiap Puskesmas di wilayahnya. Tetapi di Instalasi Farmasi Dinas Kesehatan Kota Surakarta tidak melakukan sesuai dengan indikator standar tersebut, melainkan menunggu adanya surat pesanan dari Puskesmas - Puskesmas yang ada di Kota Surakarta. Surat Pesanan ini kemudian disiapkan terlebih dahulu oleh petugas dan setelah semuanya siap maka Instalasi Farmasi Dinas Kesehatan Kota Surakarta menghubungi pihak Puskesmas yang melakukan pesanan untuk mengambil obat tersebut.

Adapun lima Puskesmas yang pendistribusiannya tepat ini dikarenakan pada hari Puskesmas dihubungi oleh pihak Instalasi Farmasi Dinas Kesehatan Kota Surakarta untuk mengambil pesanan, Puskesmas mengambil pesanan obat di hari yang sama. Sedangkan untuk Puskesmas yang lain ada yang baru keesokan harinya atau bahkan dua hari setelah dihubungi baru mengambil pesanan obat. Ketidaktepatan pengambilan ini kemungkinan dikarenakan ada tugas lain yang harus dilakukan di Puskesmas sehingga menunda pengambilan pesanan obat. Selain itu rendahnya tenaga kefarmasian di Puskesmas juga dapat menyebabkan tidak tepatnya waktu pengambilan pesanan obat, sehingga perlu ditambah sumber daya manusia yang berkompeten di bidangnya. Hal inilah yang mengakibatkan ketidaktepatan pendistribusian obat di Instalasi Farmasi Dinas Kesehatan Kota Surakarta.

Rencana distribusi dikatakan tepat apabila Puskesmas mengambil pesanan obat dihari yang sama ketika Puskesmas dihubungi oleh pihak Instalasi Farmasi Dinas Kesehatan Kota Surakarta. Sedangkan dikatakan tidak tepat apabila waktu pengambilan tidak sama dengan waktu Puskesmas dihubungi oleh Instalasi Farmasi Dinas Kesehatan Kota Surakarta. Untuk itu perlu dilakukan pengkajian mengenai sistem pendistribusian dari Instalasi Farmasi Dinas Kesehatan Kota Surakarta ke tingkat Puskesmas demi tercapainya ketepatan waktu pendistribusian.

\section{Tahap USE}

Tabel 7.PersentasePenyimpangan Jumlah Obat yang Digunakan

\begin{tabular}{clc}
\hline No. & Nama Obat & $\begin{array}{c}\text { Persentase } \\
(\%)\end{array}$ \\
\hline 1. & Amlodipin $5 \mathrm{mg}$ & 5.67 \\
2. & Bisoprolol $5 \mathrm{mg}$ & 10.00 \\
3. & $\begin{array}{l}\text { Diltiazem } \mathrm{HCl} 30 \\
\mathrm{mg}\end{array}$ & 15.41 \\
\hline
\end{tabular}




\begin{tabular}{|c|c|c|}
\hline 4. & Furosemide $40 \mathrm{mg}$ & 13.21 \\
\hline 5. & Furosemide injeksi & 1.91 \\
\hline 6. & $\begin{array}{l}\text { Hidroklortiazid } 25 \\
\text { mg }\end{array}$ & 5.49 \\
\hline 7. & Kaptopril 12,5 mg & 5.41 \\
\hline 8. & Kaptopril 25 mg & 7.90 \\
\hline 9. & Klonidin 0,15 mg & 6.47 \\
\hline 10. & Nifedipin & 30.04 \\
\hline 11 & Propanolol $10 \mathrm{mg}$ & 9.80 \\
\hline \multirow[t]{3}{*}{12.} & $\begin{array}{l}\text { Spironolakton } 25 \\
\text { mg }\end{array}$ & 6.82 \\
\hline & Jumlah & 118.14 \\
\hline & Rata - rata & 9.84 \\
\hline
\end{tabular}

Pada tabel terlihat bahwa dari 12 jenis obat, persentase penyimpangan jumlah obat yang digunakan di Kota Surakarta sebesar $9.84 \%$. Sedangkan angka ideal dari indikator Dinkes Provinsi Jateng (2006) adalah 0\%, sehingga dari hasil tersebut dapat disimpulkan bahwa pengelolaan obat pada tahap distribusi dengan indikator penyimpangan jumlah obat yang didistribusikan belum sesuai standar.

Terdapat beberapa faktor yang juga mempengaruhi penyimpangan jumlah obat yang didistribusikan. Faktor yang pertama adalah ketidakrasionalan permintaan dari Puskesmas yaitu jumlah permintaan tidak dihitung sesuai dengan kebutuhan yang diperlukan. Seharusnya setiap Puskesmas mengajukan surat pesanan kepada Instalasi Farmasi, permintaan obat dihitung untuk stok optimum selama satu bulan. Tetapi pada kenyataannya ada beberapa Puskesmas yang melakukan permintaan tidak berdasarkan perhitungan stok optimum. Adapun faktor yang kedua adalah stok obat di Instalasi Farmasi Dinas Kesehatan Kota Surakarta yang harus dibagi rata untuk 17 Puskesmas di Kota Surakarta selama penggunaan tahun 2015. Sebelumnya Instalasi Farmasi Dinas Kesehatan Kota Surakarta sudah melakukan perencanaan pendistribusian obat untuk tahun 2015. Sehingga permintaan dari Puskesmas tidak semuanya terpenuhi sesuai dengan permintaan yang diajukan. Kedua hal ini menjadi faktor penyebab terjadinya penyimpangan tersebut.

Persentase penyimpangan jumlah obat yang didistribusikan dapat diturunkan dengan melakukan pembinaan dan pelatihan bagi petugas pengelola obat di Instalasi Farmasi Dinas Kesehatan Kabupaten/ Kota terutama terkait dengan pengelolaan obat yang baik. Kegiatan lain yang perlu dilakukan adalah pengisian Laporan Pemakaian dan Lembar Permintaan Obat yang tepat sehingga tidak terjadi kesalahan perhitungan stok obat.

\section{Kesimpulan}

Pengelolaan obat tahap selection dan procurement di Instalasi Farmasi Dinas Kesehatan Surakarta sudah sesuai standar, tetapi pengelolaan obat pada tahap distribution dan use belum sesuai standar berdasarkan indikator pengelolaan obat Kemenkes dan WHO.

\section{Daftar Pustaka}

Anonim., 2000, Keputusan Menteri KesehatanRepublik Indonesia Nomor 633/Menkes/SK/IV/2000 tentangPembentukan Gudang PerbekalanKesehatan di BidangFarmasi di Kabupaten/kotaTertentu, 
DepartemenKesehatanRepublik Indonesia, Jakarta.

Anonim., 2008 ${ }^{\mathrm{a}}$, Keputusan Menteri KesehatanRepublik Indonesia Nomor 1121/Menkes/SK/XII/2008 tentangPedomanaTeknisPengad aanObat dan PerbekalanKesehatan di PelayananKesehatan Dasar. DepartemenKesehatanRepublik Indonesia, Jakarta.

\section{Anonim., 2009a, Undang- undangRepublik Indonesia Nomor 23 tahun 2009 tentangKesehatan, \\ DepartemenKesehatanRepublik Indonesia, Jakarta.}

Anonim., 2010, MateriPelatihanManajemenKefar masian di InstalasiFarmasiKabupaten/Kota, DirektoralJendralPelayananKefar masian dan AlatKesehatanDepartemenKeseh atanRepublik Indonesia, Jakarta.

Anonim., $2013^{a}$ PeraturanMenteriKesehatanNom or $84 \quad$ Tahun 2013 tentangPetunjukTeknisPengguna an Dana AlokasiBidangKesehatanTahunA nggaran 2014,DepartemenKesehatanRep ublik Indonesia, Jakarta.

Djatmiko, M., Anggraeni A.D., 2009, EvaluasiSistemPengelolaanObatl nstalasiPerbekalanFarmasiDinas Kesehatan Kota Semarang tahun 2007, Jurnal,Semarang :Universitas Wahid Hasyim, Volume 6.

Joko P H., 2007, AnalisisProsesPerencanaanKebu
tuhanObatPublikUntukPelayanan

KesehatanDasar (PKD) di

PuskesmasSewilayahKerja Dinas KesehatanKotaTasikmalaya,

Tesis,Semarang : Magister IImuKesehatanMasyarakat, UniversitasDiponegoro.

Kencanasari, Fudholi, Satibi., 2012, EvaluasiPengelolaanObat di DinasKesehatanKabupatenCilaca pTahun 20082009 dan 2010, JurnalManajemen dan PelayananFarmasi, volume 2 No.2 Hal. 102-107.

Pudjaningsih. D. 1996, PengembanganIndikatorEfisiensi PengelolaanObat di FarmasiRumahSakit (Tesis). Yogyakarta: Magister ManajemenRumahSakit, Program Pasca

SarjanaFakultasKedokteranUnive rsitasGadjahMada.

Quick JD, Hume ML, Ranking JR, O'Connor RW. 1997. Managing Drug Supply Second edition, revised and expanded. West Harford: KumarianPress.

WahyuningrumRetno., $\quad 2009$, Perancangan Data base untukSistemInformasiManajemen di IFRSUD Sleman Yogyakarta (Tesis). Yogyakarta: Universitas Gadjah Mada.

Wirdah, Fudholi, Pamudji., 2013, EvaluasiPengelolaanObat dan StrategiPerbaikanDenganMetode Hanlon di InstalasiFarmasiRumahSakitUmu $m$ Daerah Karel SadsuitubunKabupaten Maluku Tenggara Tahun 2012, (Tesis). Surakarta: Program Studi 
Magister ManajemenFarmasi, Universitas Setia Budi. 